\title{
Positive relationships between body weight of dairy heifers and their first-lactation and accumulated three-parity lactation production
}

\author{
R. C. Handcock, ${ }^{1 *}$ N. Lopez-Villalobos, ${ }^{1}$ L. R. McNaughton, ${ }^{2}$ P. J. Back, ${ }^{1}$ G. R. Edwards, ${ }^{3}$ and R. E. Hickson ${ }^{1}$ \\ ${ }^{1}$ School of Agriculture and Environment, Massey University, Private Bag 11-222, Palmerston North 4442, New Zealand \\ ${ }^{2}$ Livestock Improvement Corporation, Private Bag 3016, Hamilton 3240, New Zealand \\ ${ }^{3}$ Faculty of Agriculture and Life Sciences, PO Box 85084, Lincoln University, Lincoln 7647, Christchurch, New Zealand
}

\section{ABSTRACT}

This study investigated the relationships between body weight (BW) and milk production of 140,113 New Zealand dairy heifers. Heifers were classified into 5 breed groups: Holstein-Friesian, Holstein-Friesian crossbred, Jersey, Jersey crossbred, and Holstein-Friesian-Jersey crossbred. Body weights were assessed at intervals of 3 mo from 3 to 21 mo of age and their relationships with first-lactation and accumulated milk production over the first 3 lactations (3-parity) were analyzed. We found positive curvilinear relationships between BW and milk production. The response to an increase in BW was greater for lighter heifers compared with heavier heifers, indicating possible benefits of preferentially feeding lighter heifers to attain heavier BW. Within the age range and $\mathrm{BW}$ range studied, an increase in $\mathrm{BW}$ was always associated with an increase in first-lactation energy-corrected milk (ECM) and milk solids (milk fat plus milk protein) yield for breed groups other than Holstein-Friesian. For Holstein-Friesian heifers, there was a positive relationship between BW and ECM and milk solids yields for all ages except for 3 mo of age, when no relationship existed. These results show the potential to increase first-lactation milk production of New Zealand dairy heifers by increasing heifer BW. Likewise, for 3-parity accumulated yields, the BW at which maximum ECM and milk solids yields occurred were at the heavier end of the BW range studied. The costs of rearing a heifer are incurred regardless of how long she remains in the herd. Potential bias exists from considering only cows that survived to lactate each year if particular cows had better survival than others. Therefore, the data in the current study for 3-parity production includes all heifers that were old enough to have completed 3 lactations, regardless of whether they did or not. Including the heifers that did not complete all 3 lactations describes the effect that BW of replace-

Received June 17, 2018.

Accepted January 5, 2019.

*Corresponding author: R.C.Handcock@massey.ac.nz ment heifers has on accumulated milk yields without discriminating whether the increased milk yield came from greater survival or from greater production per surviving cow. Further research on the relationships between BW and survival of heifers is required to confirm whether the heavier heifers survived longer than the lighter heifers, but could explain why the relationship between BW and 3-parity milk yields was more curvilinear than the relationship between BW and firstlactation milk production. Holstein-Friesian heifers that were $450 \mathrm{~kg}$ in BW at 21 mo of age were estimated to produce 168 and $509 \mathrm{~kg}$ more ECM than $425-\mathrm{kg}$ Holstein-Friesian heifers in first-lactation and 3-parity accumulated yields, respectively. A further increase in BW at 21 mo of age, from 450 to $475 \mathrm{~kg}$, was estimated to result in 157 and $409 \mathrm{~kg}$ more ECM in firstlactation and 3-parity accumulated yields, respectively. Consequently, for heifers that were average and below average in BW, considerable milk production benefits would occur over the first 3 lactations by improving rearing practices to result in heavier heifers throughout the precalving phase.

Key words: body weight, milk yield, accumulated yield, growth

\section{INTRODUCTION}

Replacement dairy heifers are required to calve at 24 mo of age to maintain the 365-d calving interval required in a seasonal pasture-based dairy farming system. In year-round calving systems, an age at first calving between 22 and 24 mo of age is recommended for optimal economic returns (Ettema and Santos, 2004; Hutchison et al., 2017). To calve at 24 mo of age, heifers need to have attained puberty by and get pregnant at 15 mo of age. Puberty in heifers occurs between approximately 45 to $55 \%$ of mature BW (McNaughton et al., 2002; Freetly et al., 2011). To ensure that heifers have attained puberty before breeding, the industry-recommended target $\mathrm{BW}$ at breeding is $60 \%$ of mature BW (Troccon, 1993; Wathes et al., 2014). More beef heifers that were bred to their third estrus 
were pregnant $(78 \%)$ compared with heifers that were bred to their first estrus (57\%), suggesting that fertility improves over the first few estrous cycles (Byerley et al., 1987). Therefore, it is advantageous to have all heifers pubertal before breeding.

Generally, in a seasonal pasture-based dairy farming system, all of the cows in the herd are dried off around the same time; therefore, cows that calved earlier in the calving period will have had a longer lactation compared with cows that calved later, enabling more productive days and, hence, greater milk yields (Macdonald et al., 2008). A greater proportion of heifers that calved early (within $21 \mathrm{~d}$ of herd planned start of calving) also calved early (within $42 \mathrm{~d}$ of herd planned start of calving) after first lactation compared with heifers that calved later (after $21 \mathrm{~d}$ from herd planned start of calving; Pryce et al., 2007). This emphasizes the importance of early-calving heifers, as they are likely to become early-calving cows. More heifers that were heavier at breeding were pubertal and calved earlier than heifers that were lighter at breeding (Archbold et al., 2012). In addition, more of the heavier heifers were present at the beginning of first (93 vs. $82 \%$ ) and second (76 vs. $62 \%$ ) lactation compared with the lighter heifers (Archbold et al., 2012), further emphasizing the reproductive and longevity benefits of having heavier heifers at breeding.

Positive linear relationships between precalving BW and first-lactation milk production as well as percentage of target BW and milk production have been reported in New Zealand (van der Waaij et al., 1997; McNaughton and Lopdell, 2013). Those studies estimated 5 to $6 \mathrm{~L}$ of milk was produced in the first lactation for each extra kilogram of BW between 9 and 22 mo of age. McNaughton and Lopdell (2013) also reported a similar effect of BW between 15 to 18 mo of age on second-lactation yields $(4.8 \mathrm{~L} / \mathrm{kg}$ of BW). These results indicate that greater milk production can be achieved in first and second lactations by growing heifers to greater BW, but a curvilinear relationship was not considered in these studies.

The major dairy breeds in New Zealand are HolsteinFriesian (33.0\%), Jersey (9.3\%), and Holstein-FriesianJersey crossbred $(48.0 \%)$, with a large range of Holstein-Friesian and Jersey breed proportions within the crossbreeds. Jersey heifers produced less milk (Sneddon et al., 2016; Livestock Improvement Corporation and DairyNZ, 2017) and were lighter (Handcock et al., 2018) than Holstein-Friesian-Jersey crossbred and Holstein-Friesian heifers. The aforementioned milk production studies (van der Waaij et al., 1997; McNaughton and Lopdell, 2013) did not compare the relationships between BW and milk production among heifers of differing breed makeup.
The recommended target BW for dairy heifers in New Zealand and elsewhere are based on percentages of mature BW (Troccon, 1993; NRC, 2001; Wathes et al., 2014). The target growth trajectory between the target BW is predominantly linear; however, heifer growth in a seasonal pasture-based system did not follow the linear trajectory that the target BW necessitated (Handcock et al., 2018). Furthermore, the growth pattern of Holstein-Friesian, Jersey and their crossbred heifers differed throughout the rearing phase (Handcock et al., 2018), suggesting possible breed-specific optimum BW to yield maximum milk production. The aim of the current study was to explore the relationships between precalving BW and milk production in New Zealand dairy heifers of varying breed makeup over multiple lactations.

\section{MATERIALS AND METHODS}

\section{Initial Data Set}

The initial data set was extracted from the Livestock Improvement Corporation internal national dairy database and consisted of 189,936 spring-born heifers born between the 2006 and 2007 and 2013 and 2014 spring-calving dairy seasons and located in 1,547 herds throughout New Zealand. Heifers were included if they had at least $2 \mathrm{BW}$ records between birth and 12 mo of age and at least $2 \mathrm{BW}$ records between 13 mo of age and first calving at 2 yr of age (between June and December) or 24 mo of age for heifers that did not have a recorded calving date at $2 \mathrm{yr}$ of age. Growth curves were generated for each heifer using random regression of a fourth-order Legendre polynomial in ASReml (Gilmour et al., 2015), as described by Handcock et al. (2018). Using the regression coefficients from the growth curves, BW were predicted for each heifer at 3 , $6,9,12,15,18$, and 21 mo of age in SAS version 9.4 (SAS Institute Inc., Cary, NC).

Breed composition (expressed in sixteenths) based on pedigree information was used to classify heifers into 1 of 5 breed groups: Holstein-Friesian $(\mathbf{F})$, HolsteinFriesian crossbred (FX), Jersey $(\mathbf{J})$, Jersey crossbred $(\mathbf{J X})$, or Holstein-Friesian-Jersey crossbred $(\mathbf{F J})$. The criteria used to classify breed groups are outlined in Table 1. All heifers in the data set were 16/16 pedigree recorded and were no more than 2/16 of any breed other than Holstein-Friesian or Jersey.

\section{First-Lactation Data Set}

Additional data of calving dates and milk production records were extracted from the Livestock Improvement 
Table 1. Breed composition and number of records (N) for Holstein-Friesian (F), Holstein-Friesian crossbred (FX), Holstein-Friesian-Jersey crossbred (FJ), Jersey crossbred (JX), and Jersey (J) heifers included in the $\mathrm{BW}$, first-lactation (FL), and accumulated 3-parity production (3-parity) data sets

\begin{tabular}{llrrr}
\hline $\begin{array}{l}\text { Breed } \\
\text { group }\end{array}$ & Breed composition & $\mathrm{N}(\mathrm{BW})$ & $\mathrm{N}(\mathrm{FL})$ & $\mathrm{N}(\text { 3-parity })^{1}$ \\
\hline $\mathrm{F}$ & $\mathrm{F} \geq 14 / 16$ & 47,852 & 34,936 & 16,382 \\
$\mathrm{FX}$ & $10 / 16 \leq \mathrm{F} \leq 13 / 16$ & 62,310 & 46,690 & 22,192 \\
$\mathrm{FJ}$ & $\mathrm{F}<10 / 16$ and J $<10 / 16$ & 42,842 & 31,373 & 15,154 \\
$\mathrm{JX}$ & $10 / 16 \leq \mathrm{J} \leq 13 / 16$ & 24,184 & 17,395 & 8,672 \\
$\mathrm{~J}$ & $\mathrm{~J} \geq 14 / 16$ & 12,352 & 9,719 & 5,433 \\
Total & & 189,936 & 140,113 & 67,833 \\
\hline
\end{tabular}

${ }^{1}$ Only heifers born between spring 2006/07 and spring 2012/13 were included for 3-parity analysis.

Corporation database and merged with the growth curves of the 189,936 heifers. Heifers were selected that calved at approximately 2 yr of age (21-29 mo of age) in the spring-calving period (between June and December; $\mathrm{n}=175,142)$.

Heifers with a first-lactation length of less than $80 \mathrm{~d}$ were excluded; additionally, we also excluded records outside of 30 to $300 \mathrm{~kg}$ of milk protein, 40 to $400 \mathrm{~kg}$ of milk fat, and 800 to $8,000 \mathrm{~L}$ of milk yield. Lactations that were greater than $305 \mathrm{~d}$ were truncated at 305 d. This resulted in 140,113 heifers with suitable firstlactation records located in 1,326 herds (Table 1 ).

\section{Three-Parity Production Data Set}

A data set was created to examine the effect of BW on milk production accumulated over the first 3 lactations (3-parity production), provided the heifer was old enough to complete 3 lactations. The starting data set was the first-lactation data set and was merged with second and third calving dates and milk production records that were extracted from the Livestock Improvement Corporation database (2008-2009 to 2016-2017 spring-calving dairy seasons).

Heifers born after the 2012 to 2013 spring-calving dairy season $(\mathrm{n}=50,584)$ were removed from the data set, as they were not old enough to have had 3 full lactations at the time of data extraction. The remaining 89,529 heifers were subject to the following criteria: heifers with a calving date but no milk yields ( $\mathrm{n}=$ $12,445)$ were removed from the data set due to uncertainty as to whether they were not herd tested or if they did not lactate. Second- and third-lactation yields were subject to the same criteria as first-lactation yields; that is, 30 to $300 \mathrm{~kg}$ of milk protein, 40 to $400 \mathrm{~kg}$ of milk fat, 800 to $8,000 \mathrm{~L}$ of milk yield, and lactation length of greater than $80 \mathrm{~d}$. Any heifer with a record outside of those limits $(\mathrm{n}=9,251)$ was excluded from the analysis. Lactations that were longer than $305 \mathrm{~d}$ were truncated at $305 \mathrm{~d}$ to remove any heifers that were milked for extended lactations that were atypical of the New Zealand system.

Three-parity production was calculated as the sum of milk, fat, or protein yields up to the first 3 lactations. Three-parity production was equivalent to first-parity production for heifers that did not have a recorded second calving date. Likewise, 3-parity production was equivalent to the sum of first- and second-parity production for heifers that did not have a recorded third calving date. After these data edits, 67,833 heifers that were located in 1 of 910 herds during first lactation remained in the data set (Table 1 ).

\section{Data Handling}

The ECM yield formula used was from Beever and Doyle (2007) and derived from Tyrrell and Reid (1965) and calculated as

$$
\begin{aligned}
& \mathrm{ECM}=\text { milk yield } \times(383 \times \text { fat percentage } \\
& +242 \times \text { protein percentage }+783.2) / 3,140 .
\end{aligned}
$$

Milk solids were calculated as the sum of milk fat and milk protein yields (lactose not included).

\section{Statistical Analysis}

Least squares means for each breed group for firstlactation and 3-parity milk parameters were obtained using mixed models in SAS version 9.4 (SAS Institute Inc.). The models included the fixed effects of breed group (F, FX, FJ, JX, J), the covariate deviation from median date of first calving (within herd-year), and the random effect of herd-year. Herd-year was defined as the herd and year in which the heifer was located during first lactation.

Body weights were considered at 3, 6, 9, 12, 15, 18, and 21 mo of age. The effects of BW on milk production parameters in first-lactation and 3-parity production 
were analyzed using mixed models; BW at each age were fitted separately. The models included the fixed effects of breed group (F, FX, FJ, JX, J), the linear and quadratic effects of BW within breed group, the covariate deviation from median date of first calving (within herd-year), and the random effect of herd-year.

For each breed group-age combination, BW at which maximum milk production was observed was determined by calculating the BW at which the first derivative with respect to $\mathrm{BW}$ of the solution from the mixed model was zero for models in which the quadratic effect of BW was significant $(P<0.05)$.

\section{RESULTS}

\section{Breed Group Milk Production}

Jersey heifers produced the least $(P<0.01)$ ECM and milk solids in first and 3-parity lactations (Table $2)$. First-lactation yields of ECM were greater $(P<$ 0.01) for FX heifers compared with F heifers. HolsteinFriesian and FJ heifers had similar $(P>0.05)$ ECM yields in first lactation, but accumulated 3-parity ECM yields were lesser $(P<0.01)$ for $\mathrm{F}$ than $\mathrm{FX}$ and $\mathrm{FJ}$ heifers.

Milk solids production of FX and FJ heifers were similar $(P>0.05)$ in first and 3-parity lactations (Table 2). Furthermore, 3 -parity milk solids production was not different $(P>0.05)$ for $\mathrm{F}$ and JX heifers, both produced less $(P<0.01)$ than FX and FJ heifers but more $(P<0.01)$ than $\mathrm{J}$ heifers (Table 2$)$.

\section{First Lactation}

Body weight at 3 to 21 mo of age had significant linear and quadratic effects on first-lactation milk yields
(Table 3 and Table 4). Heifers of all breed groups that were heavier at $6,9,12,15,18$, and 21 mo of age produced more ECM and milk solids compared with heifers that were lighter $(P<0.05$; Table 3 and Table 4$)$. For $\mathrm{F}$ heifers, there was a positive relationship between BW and milk production for all ages except for 3 mo of age, when no relationship existed $(P>0.05$; Table 3 and Table 4). The linear effects of BW were positive and the quadratic effects of BW were negative and were more likely to be significant at older ages $(15,18$, and 21 mo of age) compared with younger ages (less than 15 mo of age; Table 3 and Table 4).

The relationship between BW and ECM yields for FJ heifers is depicted in Figure 1. It illustrates that the relationship is linear when heifers were 3 mo of age and curvilinear when heifers were 6 mo of age and older. The ECM yield response to increasing BW is greater in lighter heifers than heavier heifers aged 6 to 21 mo of age, with no observed maximum response within the BW range observed (Table 5).

Jersey heifers had significant linear and quadratic effects for BW at 3 mo of age for ECM yields, whereas $\mathrm{F}$ heifers had no significant relationship between BW and ECM yields. Other breed groups (FX, FJ, and JX) had a linear relationship between BW and ECM yield (Table 3). In contrast, BW at 21 mo of age had significant linear and quadratic effects on ECM for all breed groups (Table 3). Based on the $95 \%$ confidence intervals, we found limited differences in ECM yield between heifers of differing breed groups when they were similar in BW at 21 mo of age. For example, 380-kg F heifers were estimated to produce $3,570 \pm 21 \mathrm{~kg}$ of ECM and $380-\mathrm{kg} \mathrm{J}$ heifers were estimated to produce similarly at $3,654 \pm 23 \mathrm{~kg}$. In addition, 450-kg 21-mo-old heifers were estimated to produce $4,068 \pm 19$ and 4,057 \pm 35 $\mathrm{kg}$ of ECM for F and J, respectively. At the heavier end

Table 2. Number of records $(\mathrm{N})$ and $\mathrm{LSM} \pm$ SEM of ECM and milk solids ${ }^{1}(\mathrm{MS})$ in first-lactation and accumulated 3-parity production for Holstein-Friesian (F), Holstein-Friesian crossbred (FX), Holstein-FriesianJersey crossbred (FJ), Jersey crossbred (JX), and Jersey (J) cows

\begin{tabular}{lccc}
\hline Item & $\mathrm{N}$ & $\mathrm{ECM}(\mathrm{kg})$ & $\mathrm{MS}(\mathrm{kg})$ \\
\hline First lactation & & & \\
F & 34,936 & $3,970.8^{\mathrm{b}} \pm 19.9$ & $301.6^{\mathrm{b}} \pm 1.5$ \\
FX & 46,690 & $3,997.3^{\mathrm{a}} \pm 19.7$ & $305.6^{\mathrm{a}} \pm 1.5$ \\
FJ & 31,373 & $3,971.7^{\mathrm{b}} \pm 19.9$ & $305.0^{\mathrm{a}} \pm 1.5$ \\
JX & 17,395 & $3,894.0^{\mathrm{c}} \pm 20.2$ & $300.0^{\mathrm{c}} \pm 1.5$ \\
J & 9,719 & $3,694.5^{\mathrm{d}} \pm 23.1$ & $286.1^{\mathrm{d}} \pm 1.8$ \\
Three-parity & & & $782.5^{\mathrm{b}} \pm 7.9$ \\
F & & $10,311.0^{\mathrm{b}} \pm 102.5$ & $813.1^{\mathrm{a}} \pm 7.7$ \\
FX & 16,382 & $10,635.0^{\mathrm{a}} \pm 99.7$ & $816.9^{\mathrm{a}} \pm 7.9$ \\
FJ & 22,192 & $10,624.0^{\mathrm{a}} \pm 102.3$ & $792.3^{\mathrm{b}} \pm 8.2$ \\
JX & 15,154 & $10,264.0^{\mathrm{b}} \pm 107.1$ & $735.0^{\mathrm{c}} \pm 10.8$ \\
J & 8,672 & $9,466.0^{\mathrm{c}} \pm 140.4$ & \\
\hline
\end{tabular}

${ }^{\mathrm{a}-\mathrm{d}}$ Values within column and parameter with different superscripts differ between breed groups $(P<0.01)$.

${ }^{1}$ Where milk solids were calculated as the sum of milk fat and milk protein yields.

${ }^{2}$ Only heifers born between spring 2006/07 and spring 2012/13 were included for 3-parity analysis. 
Table 3. Intercept and regression coefficients \pm SE for the linear and quadratic effects of BW of dairy heifers on ECM yield in first lactation

\begin{tabular}{|c|c|c|c|c|c|c|}
\hline Breed group ${ }^{1}$ & $\begin{array}{c}\text { Intercept } \\
(\mathrm{kg} \text { of ECM })\end{array}$ & $P$-value ${ }^{2}$ & $\begin{array}{c}\text { Linear } \\
(\mathrm{kg} \text { of } \mathrm{ECM} / \mathrm{kg} \text { of } \mathrm{BW})\end{array}$ & $P$-value & $\begin{array}{c}\text { Quadratic } \\
\left(\mathrm{kg} \text { of } \mathrm{ECM} / \mathrm{kg} \text { of } \mathrm{BW}^{2}\right)\end{array}$ & $P$-value \\
\hline \multicolumn{7}{|l|}{$3 \mathrm{mo}$ of age } \\
\hline $\mathrm{F}$ & $3,380.1 \pm 128.1$ & $<0.001$ & $4.32 \pm 2.65$ & 0.102 & $0.0242 \pm 0.0137$ & 0.078 \\
\hline FJ & $3,132.2 \pm 123.7$ & $<0.001$ & $10.05 \pm 2.75$ & $<0.001$ & $-0.0030 \pm 0.0154$ & 0.844 \\
\hline JX & $3,103.2 \pm 155.8$ & $<0.001$ & $10.41 \pm 3.58$ & 0.004 & $-0.0101 \pm 0.0206$ & 0.624 \\
\hline $\mathrm{J}$ & $2,370.8 \pm 218.9$ & $<0.001$ & $23.37 \pm 5.22$ & $<0.001$ & $-0.0803 \pm 0.0311$ & 0.010 \\
\hline FJ & $2,161.4 \pm 159.1$ & $<0.001$ & $14.75 \pm 2.09$ & $<0.001$ & $-0.0163 \pm 0.0069$ & 0.018 \\
\hline JX & $2,339.5 \pm 201.1$ & $<0.001$ & $12.25 \pm 2.73$ & $<0.001$ & $-0.0094 \pm 0.0092$ & 0.309 \\
\hline $\mathrm{J}$ & $2,224.3 \pm 286.1$ & $<0.001$ & $12.12 \pm 4.11$ & 0.003 & $-0.0087 \pm 0.0147$ & 0.553 \\
\hline \multicolumn{7}{|l|}{9 mo of age } \\
\hline $\mathrm{F}$ & $1,957.1 \pm 176.5$ & $<0.001$ & $11.22 \pm 1.73$ & $<0.001$ & $-0.0042 \pm 0.0042$ & 0.326 \\
\hline FX & $2,045.2 \pm 150.6$ & $<0.001$ & $10.66 \pm 1.52$ & $<0.001$ & $-0.0023 \pm 0.0038$ & 0.553 \\
\hline FX & $1,830.9 \pm 172.1$ & $<0.001$ & $9.28 \pm 1.39$ & $<0.001$ & $-0.0010 \pm 0.0028$ & 0.728 \\
\hline FJ & $1,295.7 \pm 214.8$ & $<0.001$ & $13.81 \pm 1.80$ & $<0.001$ & $-0.0101 \pm 0.0037$ & 0.007 \\
\hline JX & $1,499.2 \pm 284.0$ & $<0.001$ & $12.43 \pm 2.46$ & $<0.001$ & $-0.0083 \pm 0.0053$ & 0.119 \\
\hline $\mathrm{J}$ & $910.8 \pm 438.6$ & 0.038 & $16.74 \pm 4.04$ & $<0.001$ & $-0.0174 \pm 0.0092$ & 0.061 \\
\hline \multicolumn{7}{|l|}{15 mo of age } \\
\hline $\mathrm{F}$ & $770.8 \pm 249.1$ & 0.002 & $12.88 \pm 1.53$ & $<0.001$ & $-0.0083 \pm 0.0023$ & $<0.001$ \\
\hline $\mathrm{FX}$ & $997.8 \pm 218.1$ & $<0.001$ & $11.79 \pm 1.39$ & $<0.001$ & $-0.0064 \pm 0.0022$ & 0.004 \\
\hline FJ & $588.7 \pm 271.7$ & 0.030 & $14.56 \pm 1.79$ & $<0.001$ & $-0.0106 \pm 0.0030$ & $<0.001$ \\
\hline JX & $445.8 \pm 350.4$ & 0.203 & $16.14 \pm 2.40$ & $<0.001$ & $-0.0144 \pm 0.0041$ & $<0.001$ \\
\hline $\mathrm{J}$ & $57.9 \pm 522.8$ & 0.912 & $18.22 \pm 3.85$ & $<0.001$ & $-0.0175 \pm 0.0071$ & 0.013 \\
\hline \multicolumn{7}{|l|}{18 mo of age } \\
\hline $\mathrm{F}$ & $329.1 \pm 303.1$ & 0.278 & $12.27 \pm 1.50$ & $<0.001$ & $-0.0073 \pm 0.0019$ & $<0.001$ \\
\hline $\mathrm{FX}$ & $-81.1 \pm 267.1$ & 0.761 & $14.77 \pm 1.38$ & $<0.001$ & $-0.0104 \pm 0.0018$ & $<0.001$ \\
\hline FJ & $88.5 \pm 333.2$ & 0.791 & $14.08 \pm 1.78$ & $<0.001$ & $-0.0095 \pm 0.0024$ & $<0.001$ \\
\hline
\end{tabular}

${ }^{1}$ Where F is Holstein-Friesian, FX is Holstein-Friesian crossbred, FJ is Holstein-Friesian-Jersey crossbred, JX is Jersey crossbred, and J is Jersey.

${ }^{2} P$-value tests that the corresponding regression coefficient is significantly different from zero.

of the $\mathrm{BW}$ range for $\mathrm{J}$ heifers $(>430 \mathrm{~kg})$, FJ and $\mathrm{FX}$ heifers produced more ECM than J heifers. In contrast, for BW at 3 mo of age, $\mathrm{J}$ heifers produced less ECM at all BW compared with F, FX, and FJ heifers, and for BW less than $125 \mathrm{~kg}$ produced less than JX heifers. All other breed groups produced similar quantities of ECM when they were similar in BW at 3 mo of age.

When the quadratic effect was significant, the first derivative of the equation was used to estimate at which BW the maximum yield occurred (Table 5). At all ages studied, the BW at which maximum ECM yields occurred were greater than the maximum BW of heifers in the data set. The maximum milk solids yield occurred for $\mathrm{J}$ heifers that were $142 \mathrm{~kg}$ at 3 mo of age (maximum observed BW was $143 \mathrm{~kg}$ ). For all other breed groups and ages, the estimated BW at which maximum milk solids yield was attained was greater than the BW range studied.

\section{Three-Parity Production}

Out of the 67,833 cows for which 3-parity production was reported, 44,851 (66.1\%) had 3 lactations, 10,146 (15.0\%) had first and second lactation only, and 12,836 $(18.9 \%)$ had first lactation only.

Body weight from 3 to 21 mo of age had significant linear and quadratic effects on 3-parity milk production (Tables 6 and 7). Similar to first-lactation yields, heifers that were heavier produced more 3-parity ECM and milk solids compared with heifers that were lighter. 
When significant, the linear effects were positive and the quadratic effects were negative (Tables 6 and 7 ). For FJ and JX heifers, there was always a relationship between BW and 3-parity milk production, whereas for $\mathrm{F}, \mathrm{FX}$, and $\mathrm{J}$ heifers some ages (3 and $6 \mathrm{mo}$ of age) had no significant relationship (Tables 6 and 7). Similar to the relationship with first-lactation yields, the quadratic effects of BW were more often significant at older ages (9-21 mo of age) compared with younger ages (3 and 6 mo of age), except for FJ heifers, where the relationship was always curvilinear (Tables 6 and 7).
In contrast to first-lactation yields, for all breeds the majority of ages studied had a BW at which maximum 3 -parity yields were achieved within the $\mathrm{BW}$ range studied (Table 5), all of which were greater than the mean BW and closer to the heavier end of the BW range (Table 5). For example, the BW of 21-mo-old FJ heifers at which maximum ECM and milk solids yields were estimated to occur at was more than $90 \mathrm{~kg}$ heavier than the mean BW of $420 \mathrm{~kg}$ and nearer to the maximum BW observed of $582 \mathrm{~kg}$ (Table 5).

The relationship between BW and 3-parity ECM yields for FJ heifers is depicted in Figure 2; it illus-

Table 4. Intercept and regression coefficients \pm SE for the linear and quadratic effects of BW of dairy heifers on milk solids ${ }^{1}$ (MS) yield in first lactation

\begin{tabular}{|c|c|c|c|c|c|c|}
\hline Breed group ${ }^{2}$ & $\begin{array}{l}\text { Intercept } \\
\text { (kg of MS) }\end{array}$ & $P$-value ${ }^{3}$ & $\begin{array}{c}\text { Linear } \\
(\mathrm{kg} \text { of } \mathrm{MS} / \mathrm{kg} \text { of } \mathrm{BW})\end{array}$ & $P$-value & $\begin{array}{c}\text { Quadratic } \\
\left(\mathrm{kg} \text { of } \mathrm{MS} / \mathrm{kg} \text { of } \mathrm{BW}^{2}\right)\end{array}$ & $P$-value \\
\hline \multicolumn{7}{|l|}{3 mo of age } \\
\hline $\mathrm{F}$ & $259.4 \pm 9.8$ & $<0.001$ & $0.31 \pm 0.20$ & 0.126 & $0.0017 \pm 0.0011$ & 0.100 \\
\hline FJ & $241.8 \pm 9.5$ & $<0.001$ & $0.77 \pm 0.21$ & $<0.001$ & $-0.0004 \pm 0.0012$ & 0.735 \\
\hline JX & $240.9 \pm 12.0$ & $<0.001$ & $0.80 \pm 0.28$ & 0.004 & $-0.0010 \pm 0.0016$ & 0.544 \\
\hline $\mathrm{J}$ & $183.2 \pm 16.8$ & $<0.001$ & $1.84 \pm 0.40$ & $<0.001$ & $-0.0065 \pm 0.0024$ & 0.007 \\
\hline $\mathrm{FX}$ & $183.4 \pm 10.1$ & $<0.001$ & $0.87 \pm 0.13$ & $<0.001$ & $-0.0004 \pm 0.0004$ & 0.334 \\
\hline FJ & $163.8 \pm 12.2$ & $<0.001$ & $1.17 \pm 0.16$ & $<0.001$ & $-0.0014 \pm 0.0005$ & 0.008 \\
\hline JX & $179.3 \pm 15.5$ & $<0.001$ & $0.97 \pm 0.21$ & $<0.001$ & $-0.0009 \pm 0.0007$ & 0.228 \\
\hline $\mathrm{J}$ & $170.0 \pm 22.0$ & $<0.001$ & $0.98 \pm 0.32$ & 0.002 & $-0.0008 \pm 0.0011$ & 0.456 \\
\hline \multicolumn{7}{|l|}{9 mo of age } \\
\hline $\mathrm{F}$ & $155.9 \pm 13.6$ & $<0.001$ & $0.79 \pm 0.13$ & $<0.001$ & $-0.0002 \pm 0.0003$ & 0.547 \\
\hline $\mathrm{FX}$ & $160.2 \pm 11.6$ & $<0.001$ & $0.78 \pm 0.12$ & $<0.001$ & $-0.0001 \pm 0.0003$ & 0.712 \\
\hline $\mathrm{FX}$ & $145.7 \pm 13.2$ & $<0.001$ & $0.67 \pm 0.11$ & $<0.001$ & $0.0000 \pm 0.0002$ & 0.928 \\
\hline FJ & $99.5 \pm 16.5$ & $<0.001$ & $1.07 \pm 0.14$ & $<0.001$ & $-0.0008 \pm 0.0003$ & 0.005 \\
\hline JX & $112.9 \pm 21.8$ & $<0.001$ & $0.99 \pm 0.19$ & $<0.001$ & $-0.0007 \pm 0.0004$ & 0.071 \\
\hline $\mathrm{J}$ & $63.8 \pm 33.7$ & 0.059 & $1.36 \pm 0.31$ & $<0.001$ & $-0.0015 \pm 0.0007$ & 0.034 \\
\hline \multicolumn{7}{|l|}{15 mo of age } \\
\hline $\mathrm{F}$ & $71.5 \pm 19.2$ & $<0.001$ & $0.91 \pm 0.12$ & $<0.001$ & $-0.0006 \pm 0.0002$ & 0.002 \\
\hline $\mathrm{FX}$ & $84.1 \pm 16.8$ & $<0.001$ & $0.87 \pm 0.11$ & $<0.001$ & $-0.0005 \pm 0.0002$ & 0.007 \\
\hline FJ & $45.4 \pm 20.9$ & 0.030 & $1.13 \pm 0.14$ & $<0.001$ & $-0.0009 \pm 0.0002$ & $<0.001$ \\
\hline JX & $33.6 \pm 27.0$ & 0.213 & $1.27 \pm 0.18$ & $<0.001$ & $-0.0012 \pm 0.0003$ & $<0.001$ \\
\hline \multirow{2}{*}{\multicolumn{7}{|c|}{18 mo of age }} \\
\hline & & & & & & \\
\hline $\mathrm{F}$ & $40.2 \pm 23.3$ & 0.085 & $0.87 \pm 0.12$ & $<0.001$ & $-0.0005 \pm 0.0001$ & 0.0005 \\
\hline $\mathrm{FX}$ & $2.4 \pm 20.6$ & 0.907 & $1.10 \pm 0.11$ & $<0.001$ & $-0.0008 \pm 0.0001$ & $<0.001$ \\
\hline FJ & $5.5 \pm 25.7$ & 0.831 & $1.10 \pm 0.14$ & $<0.001$ & $-0.0008 \pm 0.0002$ & $<0.001$ \\
\hline
\end{tabular}

${ }^{1}$ Where milk solids were calculated as the sum of milk fat and milk protein yields.

${ }^{2}$ Where F is Holstein-Friesian, FX is Holstein-Friesian crossbred, FJ is Holstein-Friesian-Jersey crossbred, JX is Jersey crossbred, and J is Jersey.

${ }^{3} P$-value tests that the corresponding regression coefficient is significantly different from zero. 


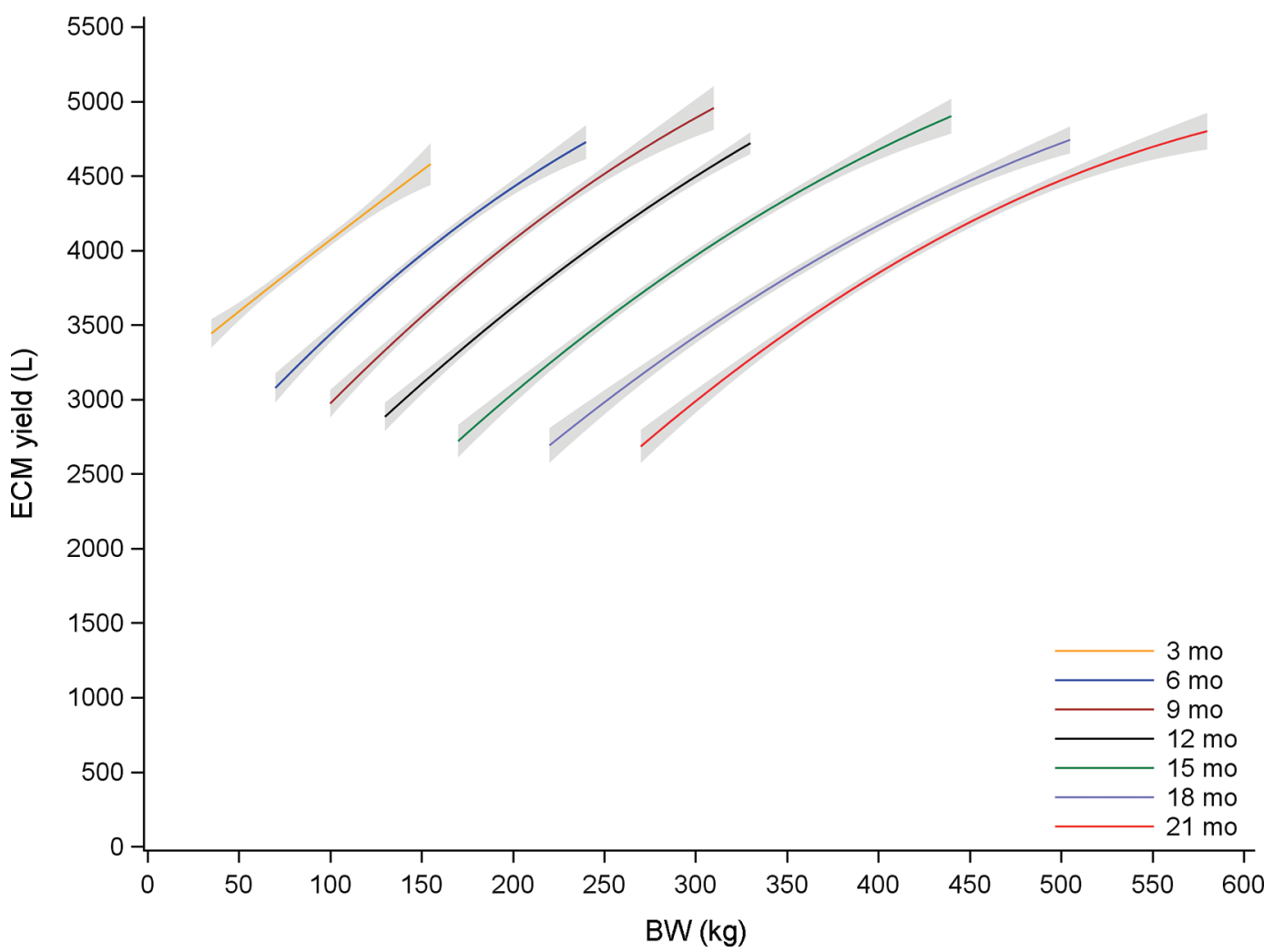

Figure 1. The relationship between BW at 3, 6, 9, 12, 15, 18, and 21 mo of age and ECM yield in first-lactation Holstein-Friesian-Jersey crossbred (FJ) dairy heifers. The BW range for each age is the range of BW observed for that age group. Gray shading indicates 95\% CI.

trates that the relationship is curvilinear for all ages. For heifers aged 12 and 15 mo, the ECM yield response to increasing BW was greater in lighter heifers than heavier heifers, with no observed maximum within the BW range studied (Figure 2 and Table 5). For all other ages, the ECM yield response to increasing BW was greater in lighter heifers than heavier heifers, up to a maximum $(145,229,290,493$, and $526 \mathrm{~kg}$, respectively, for $3,6,9,18$, and 21 mo of age; Figure 2 and Table 5).

Similar to first lactation, BW at 21 mo of age had significant linear and quadratic effects on 3-parity ECM yield for all breed groups (Table 6). Due to the significant quadratic effects for all breed groups, there were BW at which maximum ECM yields were attained within the BW range studied (Table 5); these were observed at 565, 528, 526, 486, and $485 \mathrm{~kg}$ for F, FX, FJ, $\mathrm{JX}$, and J, respectively, all at the heavier end of the BW range studied. Based on the $95 \%$ confidence intervals, we observed no differences in milk yield among the breed groups for the majority of BW at 21 mo of age. From 325 to 435, 335 to 485, and 365 to $470 \mathrm{~kg}$, respectively, JX, FJ, and FX heifers produced more ECM yields than $\mathrm{F}$ heifers. Outside of these ranges, breed groups produced similar quantities of ECM.

\section{DISCUSSION}

The relationship between precalving BW and milk production for New Zealand dairy heifers was predominantly curvilinear. Heifers that were heavier produced more milk in first lactation and 3-parity lactations than heifers that were lighter, and the response to an increase in BW was greater for lighter heifers compared with heavier heifers. This indicates potentially greater milk production benefits of preferentially feeding lighter heifers to attain heavier precalving BW.

Previous studies have reported positive relationships between precalving BW and first-lactation milk production, but have only reported linear effects (van der Waaij et al., 1997; Dobos et al., 2001; McNaughton and Lopdell, 2013; Van Eetvelde et al., 2017). Similarly, Van Amburgh et al. (1998) reported a positive relationship between postcalving BW and first-lactation milk production. The current study has included linear and quadratic effects to test if a limit existed as to how heavy heifers can be before their milk production performance was limited. The results from the present study indicate that, for F, FX, FJ, and JX, there was no BW within the range studied where a maximum 
first-lactation yield was achieved; an increase in BW at each age was associated with an increase in milk production. For $\mathrm{J}$ heifers in the current study, only one age was identified where a maximum within the BW range was observed: 3 mo of age for milk solids yield. In contrast, first-lactation Australian HolsteinFriesian heifers had estimated maximum milk, protein, and fat yields when they were 559,563 , and $568 \mathrm{~kg}$, respectively, between 24 and 33 mo of age (Dobos et al., 2001). The BW reported by Dobos et al. (2001) at which maximum milk, protein, and fat yields occurred at were similar to the BW at which maximum 3-parity milk production were estimated at in the current study for 21-mo-old F, FX, and FJ heifers.

Similar to first-lactation analyses, previous studies have reported positive linear relationships between precalving BW and second- (van der Waaij et al., 1997; McNaughton and Lopdell, 2013) and third-lactation milk production (van der Waaij et al., 1997), but have also only reported linear effects. In addition to not considering quadratic effects, potential bias exists from considering only cows that survived to lactate each year if particular cows had better survival than others; therefore, the data in the current study for 3-parity

Table 5. Mean and range of BW of dairy heifers and the BW at which the quadratic equation predicting the effect of BW on first-lactation (FL) and accumulated 3-parity (3-parity) ECM and milk solids ${ }^{1}$ (MS) yields reached a maximum (max.)

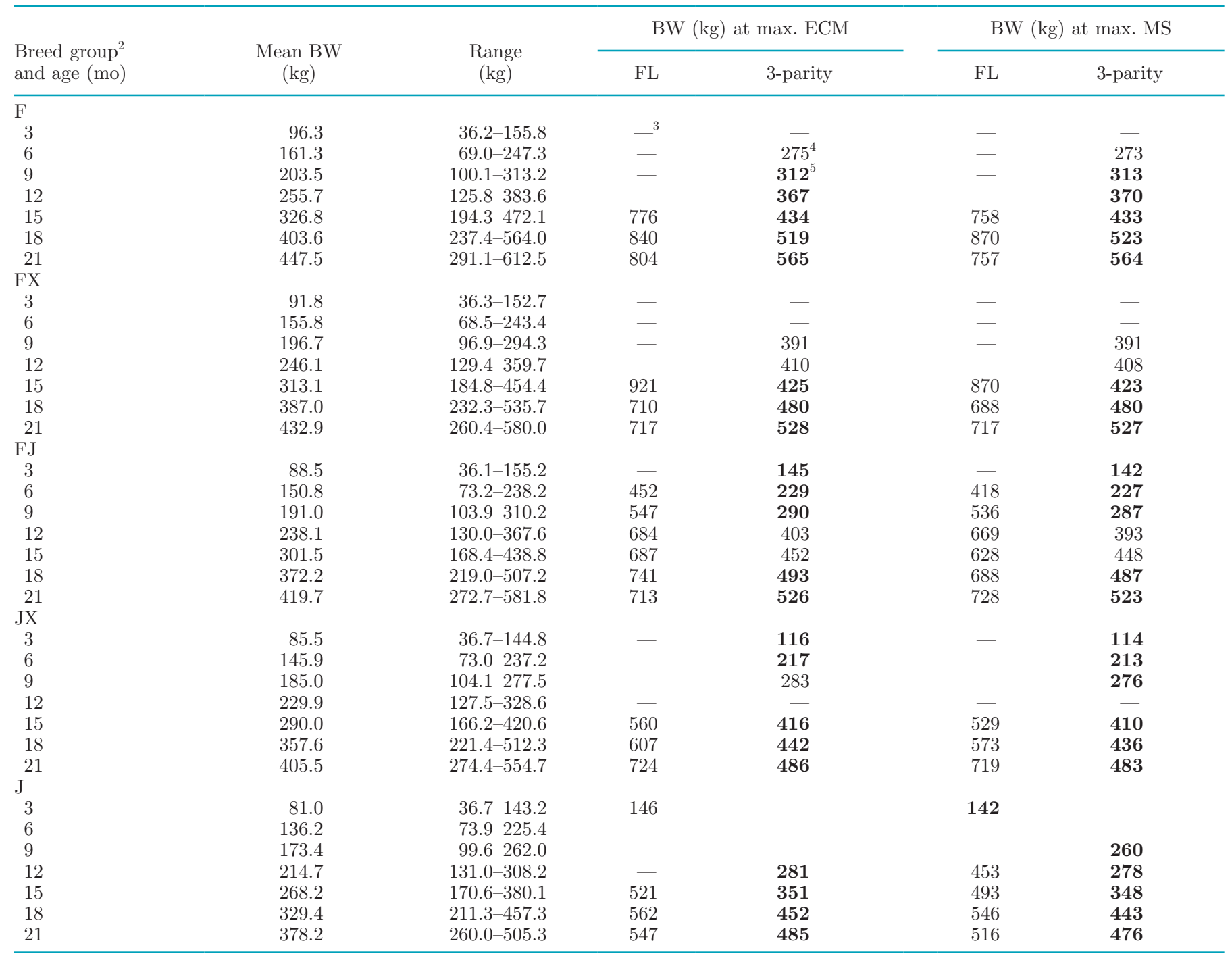

${ }^{1}$ Where milk solids were calculated as the sum of milk fat and milk protein yields.

${ }^{2}$ Where F is Holstein-Friesian, FX is Holstein-Friesian crossbred, FJ is Holstein-Friesian-Jersey crossbred, JX is Jersey crossbred, and J is Jersey. ${ }^{3}$ Dashes indicate the quadratic effect was not significant $(P>0.05)$, so no maximum was estimated.

${ }^{4}$ Nonbolded values indicate a significant quadratic effect but an estimated BW outside of the BW range observed.

${ }^{5}$ Bolded values indicate a BW at which maximum yield was estimated to occur within the BW range observed. 
Table 6. Intercept and regression coefficients \pm SE for the linear and quadratic effects of BW of dairy heifers on accumulated 3-parity ECM yield

\begin{tabular}{|c|c|c|c|c|c|c|}
\hline Breed group ${ }^{1}$ & $\begin{array}{c}\text { Intercept } \\
(\mathrm{kg} \text { of ECM })\end{array}$ & $P$-value ${ }^{2}$ & $\begin{array}{c}\text { Linear } \\
(\mathrm{kg} \text { of } \mathrm{ECM} / \mathrm{kg} \text { of } \mathrm{BW})\end{array}$ & $P$-value & $\begin{array}{c}\text { Quadratic } \\
\left(\mathrm{kg} \text { of } \mathrm{ECM} / \mathrm{kg} \text { of } \mathrm{BW}^{2}\right)\end{array}$ & $P$-value \\
\hline \multicolumn{7}{|l|}{3 mo of age } \\
\hline $\mathrm{F}$ & $7,255.6 \pm 1,099.8$ & $<0.001$ & $43.80 \pm 22.86$ & 0.055 & $-0.1052 \pm 0.1183$ & 0.374 \\
\hline FJ & $5,114.3 \pm 1,081.5$ & $<0.001$ & $92.01 \pm 23.96$ & $<0.001$ & $-0.3183 \pm 0.1324$ & 0.016 \\
\hline JX & $5,554.4 \pm 1,346.3$ & $<0.001$ & $89.89 \pm 30.82$ & 0.004 & $-0.3865 \pm 0.1753$ & 0.028 \\
\hline $\mathrm{J}$ & $5,350.5 \pm 1,850.5$ & 0.004 & $64.50 \pm 44.26$ & 0.145 & $-0.1521 \pm 0.2637$ & 0.564 \\
\hline FJ & $565.2 \pm 1,384.8$ & 0.683 & $101.76 \pm 18.09$ & $<0.001$ & $-0.2220 \pm 0.0588$ & $<0.001$ \\
\hline JX & $1,821.9 \pm 1,737.8$ & 0.295 & $89.29 \pm 23.49$ & $<0.001$ & $-0.2058 \pm 0.0790$ & 0.009 \\
\hline $\mathrm{J}$ & $3,195.6 \pm 2,344.9$ & 0.173 & $57.14 \pm 33.57$ & 0.089 & $-0.0766 \pm 0.1197$ & 0.523 \\
\hline \multicolumn{7}{|l|}{9 mo of age } \\
\hline $\mathrm{F}$ & $-2,329.4 \pm 1,573.4$ & 0.139 & $95.64 \pm 15.48$ & $<0.001$ & $-0.1535 \pm 0.0379$ & $<0.001$ \\
\hline FX & $1,902.2 \pm 1,359.5$ & 0.162 & $61.23 \pm 13.76$ & $<0.001$ & $-0.0782 \pm 0.0347$ & 0.024 \\
\hline $\mathrm{FX}$ & $-544.8 \pm 1,573.3$ & 0.729 & $66.79 \pm 12.81$ & $<0.001$ & $-0.0815 \pm 0.0260$ & 0.002 \\
\hline FJ & $-837.0 \pm 1,904.8$ & 0.660 & $69.90 \pm 16.08$ & $<0.001$ & $-0.0868 \pm 0.0338$ & 0.010 \\
\hline JX & $-177.6 \pm 2,430.8$ & 0.942 & $65.84 \pm 21.27$ & 0.002 & $-0.0849 \pm 0.0463$ & 0.067 \\
\hline $\mathrm{J}$ & $-8,073.9 \pm 3,625.2$ & 0.026 & $133.99 \pm 33.55$ & $<0.001$ & $-0.2381 \pm 0.0773$ & 0.002 \\
\hline \multicolumn{7}{|l|}{15 mo of age } \\
\hline $\mathrm{F}$ & $-7,900.7 \pm 2,197.6$ & $<0.001$ & $91.90 \pm 13.56$ & $<0.001$ & $-0.1058 \pm 0.0208$ & $<0.001$ \\
\hline FX & $-6,014.1 \pm 1,996.5$ & 0.003 & $85.97 \pm 12.79$ & $<0.001$ & $-0.1011 \pm 0.0204$ & $<0.001$ \\
\hline FJ & $-4,245.1 \pm 2,415.8$ & 0.079 & $75.28 \pm 16.11$ & $<0.001$ & $-0.0832 \pm 0.0268$ & 0.002 \\
\hline JX & $-3,999.4 \pm 3,012.7$ & 0.184 & $76.65 \pm 20.86$ & $<0.001$ & $-0.0922 \pm 0.0360$ & 0.010 \\
\hline $\mathrm{J}$ & $-10,900.0 \pm 4,200.8$ & 0.010 & $123.99 \pm 31.20$ & $<0.001$ & $-0.1766 \pm 0.0577$ & 0.002 \\
\hline \multicolumn{7}{|l|}{18 mo of age } \\
\hline $\mathrm{F}$ & $-9,241.3 \pm 2,704.6$ & 0.001 & $81.15 \pm 13.50$ & $<0.001$ & $-0.0782 \pm 0.0168$ & $<0.001$ \\
\hline FX & $-11,435.0 \pm 2,400.1$ & $<0.001$ & $97.14 \pm 12.45$ & $<0.001$ & $-0.1012 \pm 0.0161$ & $<0.001$ \\
\hline FJ & $-9,131.0 \pm 2,929.1$ & 0.002 & $86.50 \pm 15.82$ & $<0.001$ & $-0.0878 \pm 0.0213$ & $<0.001$ \\
\hline
\end{tabular}

production included all heifers that were old enough to have completed 3 lactations, regardless of whether they did or not.

Based on their first-lactation production and results from previous studies (Macdonald et al., 2005; Lembeye et al., 2016), the mean 3-parity yields for the breed groups is less than what would be expected if only cows that had completed all 3 lactations were included. This reflects the fact approximately $34 \%$ of the 67,833 heifers in the current study for 3-parity yields failed to complete all 3 lactations. The costs of rearing a heifer are incurred regardless of how long she remains in the herd. Including the heifers that did not complete all 3 lactations describes the effect that BW of replace- ment heifers has on accumulated milk yields without discriminating whether the increased milk yield came from greater survival or from greater production per surviving cow. It is possible that the lighter heifers in the current study only survived 1 or 2 lactations and, hence, their 3-parity milk yields were much lower than the heavier heifers that survived to complete 2 or 3 lactations. Nevertheless, the relationships between precalving BW and milk yield per day were consistent with the results reported here for first-lactation and 3-parity yields (data not shown).

Analyzing the relationship including only the survivors does not truly describe the effect of light heifers on milk production, as it does not take into account how 
long the heifers actually remained productive in addition to the decreased milk production (Archer et al., 2013). Further research on the relationships between BW and survival of heifers is required to confirm this but could explain why the relationship between BW and 3-parity milk yields was more curvilinear than the relationship between BW and first-lactation milk production.

Few studies have analyzed milk production accumulated over multiple lactations, the majority of which included data only from surviving cows (Bettenay, 1985; Lin et al., 1988; Heinrichs and Heinrichs, 2011; Soberon et al., 2012; Archer et al., 2013; Hutchison et al., 2017). Of these studies, only 2 examined the relationship between BW and accumulated milk production over multiple lactations (Bettenay, 1985; Heinrichs and Heinrichs, 2011), both of which concluded no relationship exists between BW and milk yield. The study by Heinrichs and Heinrichs (2011) included multiple fixed effects, such as age at first calving and age at weaning, which might have been confounded with BW at first calving. This may explain why those authors observed no relationship between BW and lifetime milk yields. In the current study, no such potential confounding effects were included in the models. Bettenay (1985) had a small sample size of 18 heifers per treatment when com-

Table 7. Intercept and regression coefficients \pm SE for the linear and quadratic effects of BW of dairy heifers on accumulated 3-parity milk solids $^{1}(\mathrm{MS})$ yield

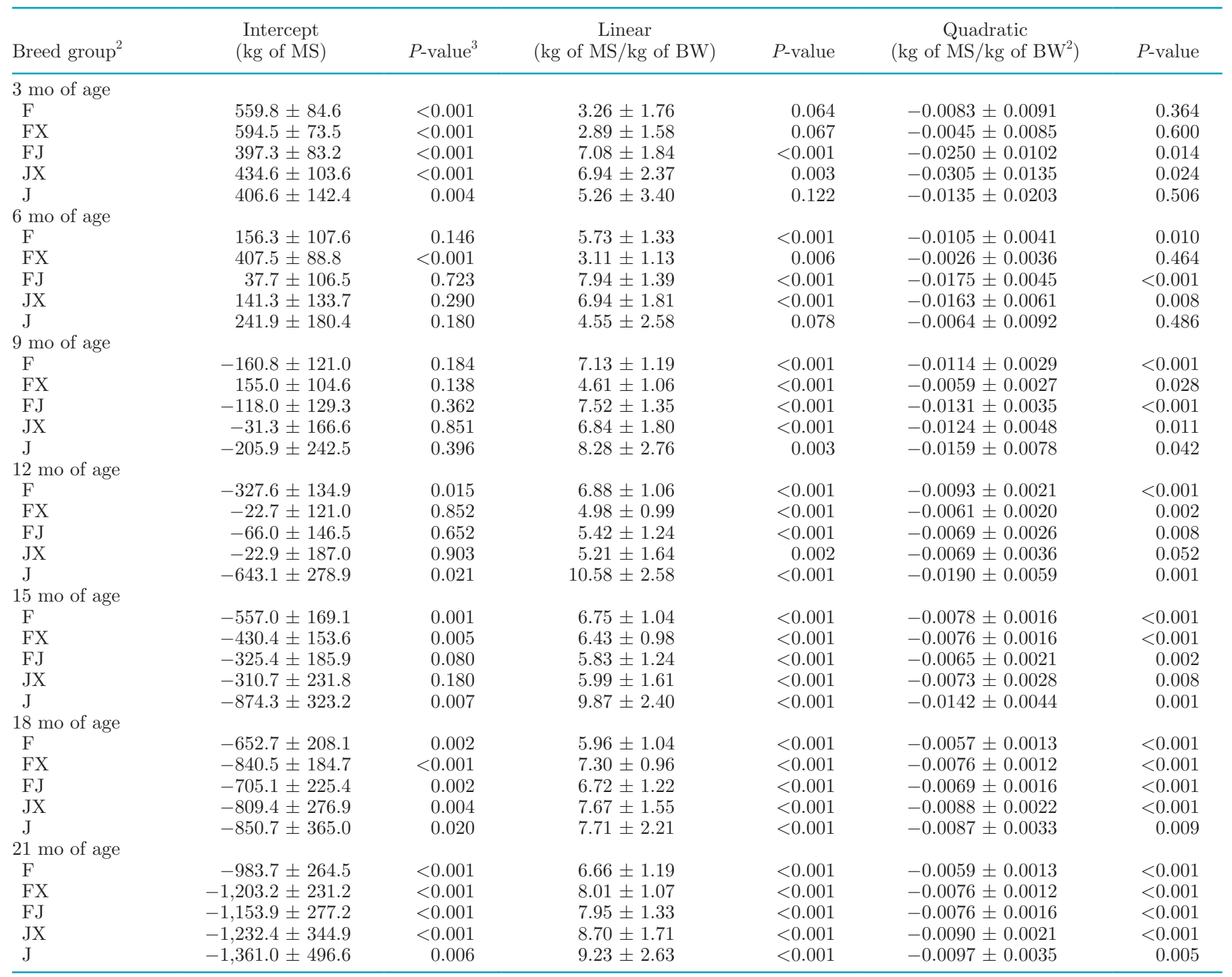

${ }^{1}$ Where milk solids were calculated as the sum of milk fat and milk protein yields.

${ }^{2}$ Where F is Holstein-Friesian, FX is Holstein-Friesian crossbred, FJ is Holstein-Friesian-Jersey crossbred, JX is Jersey crossbred, and J is Jersey.

${ }^{3} P$-value tests that the corresponding regression coefficient is significantly different from zero. 
paring 4 ages and $2 \mathrm{BW}$ at breeding. After breeding, heifers were run together, allowing the smaller heifers to grow faster and catch up to the larger heifers (Bettenay, 1985). Additionally, only heifers that completed all 4 lactations were used to estimate accumulated yield over 4 lactations. As discussed previously, this method does not fully estimate the milk production effect of the heifers that did not survive all lactations (Archer et al., 2013).

For the heifers in the current study, the periods of slowest growth occurred between 5 and 12 mo of age and between 20 and 22 mo of age (Handcock et al., 2018). The slow growth over these periods is similar to what has been reported previously in New Zealand dairy heifers (McNaughton and Lopdell, 2012). This slow growth corresponded to heifers being the furthest from target BW when they were 12 and 22 mo of age (Handcock et al., 2016). For first lactation, the 12-mo BW at which maximum yields were attained in the current study were outside of the range studied. The 12-mo BW at which maximum 3-parity yields were attained were either outside of the range studied or near the upper limit of the range studied. These results indicate that heifers may benefit from increased pasture allowances or supplementary feeding to improve growth rates leading up to 12 mo of age, with even greater benefits from feeding the lighter heifers.

To our knowledge, this is the first study that has compared milk production of Holstein-Friesians, Jerseys and various proportions of Holstein-Friesian and Jersey at similar BW. Overall, the 5 breed groups studied produced differing quantities of milk; however, throughout the majority of BW studied, heifers of differing breed makeup produced similar quantities of milk when they were the same BW precalving. These results suggest that a large proportion of the milk production advantage that $\mathrm{F}$ heifers have over $\mathrm{J}$ heifers may be due to $\mathrm{F}$ heifers being heavier than $\mathrm{J}$ heifers (Handcock et al., 2018). In the current study, the average $\mathrm{BW}$ of 21 -mo-old $\mathrm{J}$ heifers was approximately $380 \mathrm{~kg}$. The predicted first-lactation ECM yield for $380-\mathrm{kg} \mathrm{J}$ was $3,654 \mathrm{~L}$, similar to $380-\mathrm{kg} \mathrm{F}$ heifers that produced $3,570 \mathrm{~L}$. A reason these estimates were similar may be due to how well grown or close to mature BW the heifers were. The average mature BW of New Zealand cattle is 420 and $510 \mathrm{~kg}$ for $\mathrm{J}$ and F, respectively (Livestock Improvement Corporation and DairyNZ, 2017). The target BW at 21 mo of age is around 90\% mature BW (Troccon, 1993; Wathes et al., 2014). Based on the above estimates of mature BW,

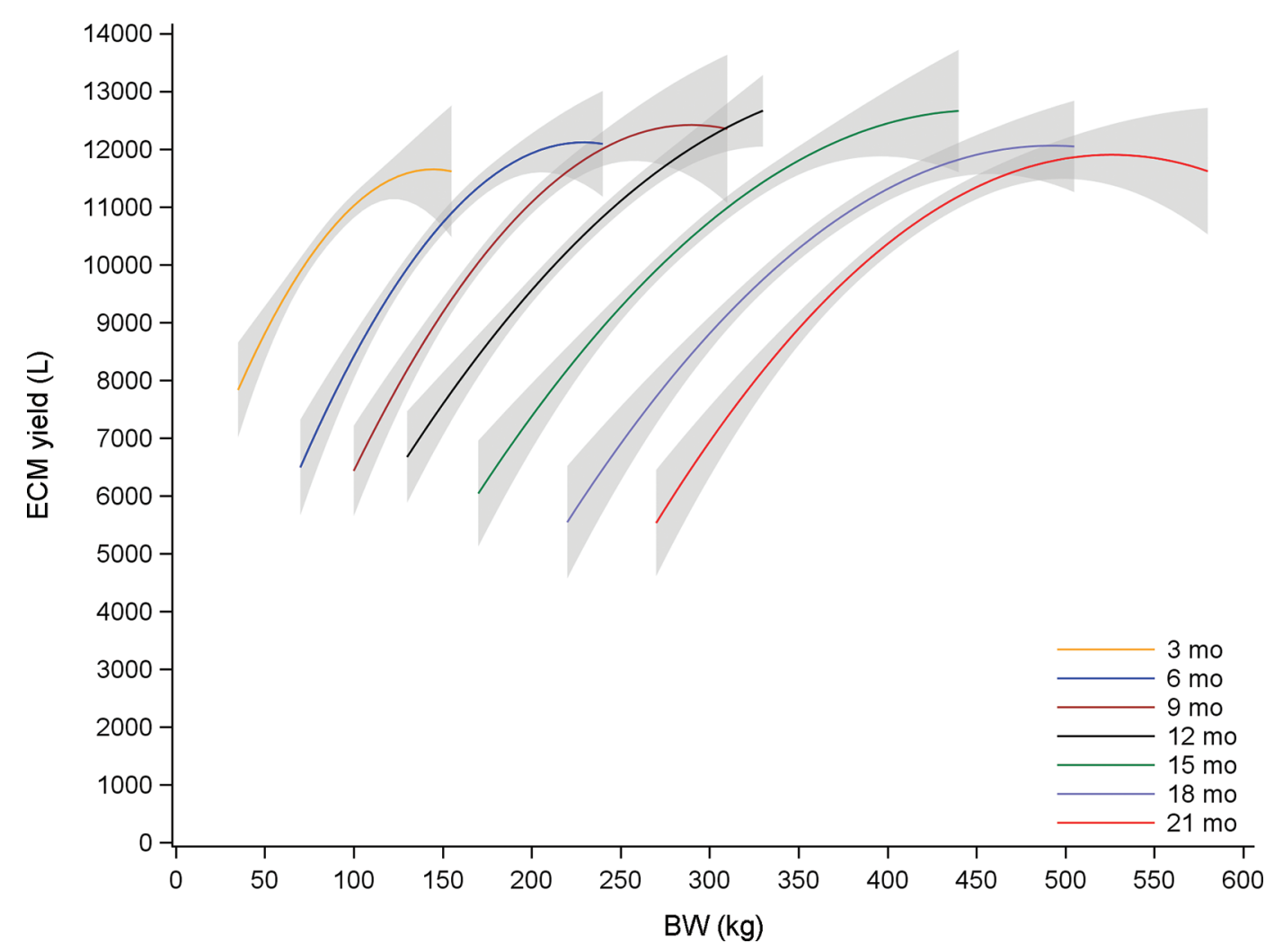

Figure 2. The relationship between BW at 3, 6, 9, 12, 15, 18, and 21 mo of age and 3-parity ECM yield for Holstein-Friesian-Jersey crossbred (FJ) dairy heifers. The BW range for each age is the range of BW observed for that age group. Gray shading indicates $95 \%$ CI. 
a 380-kg 21-mo-old J heifer would be considered well grown (90\% mature BW), whereas a 380-kg F heifer would be considered poorly grown ( $75 \%$ mature BW). The mean first-lactation ECM yield of $\mathrm{F}$ heifers was $3,971 \mathrm{~L}$, much greater than the predicted first-lactation ECM production of a 380-kg F heifer. Furthermore, the mean first-lactation ECM yield of $\mathrm{J}$ heifers was 3,695 L, similar to the predicted first-lactation ECM production of a $380-\mathrm{kg} \mathrm{J}$ heifer. There was a positive relationship between percentage of target BW and milk production of New Zealand heifers (McNaughton and Lopdell, 2013); therefore, we would expect the poorly grown $\mathrm{F}$ heifer to produce below average for $\mathrm{F}$, whereas the well-grown $\mathrm{J}$ heifer to produce near average for $\mathrm{J}$.

An alternative reason for the $\mathrm{F}$ and $\mathrm{J}$ heifers producing similar quantities of milk when they were similar in BW may be due to the considerable variation in BW within each breed group of the current study, suggesting considerable variation may exist in mature BW within each breed group as well. In the study by Archbold et al. (2012), a strong linear relationship between $\mathrm{BW}$ at 15 mo of age and mature BW was noted; the heifers that were heavier at 15 mo were also heavier at maturity. Therefore, the heifers that were lighter at 21 mo of age in the current study may have been lighter at maturity compared with heifers that were heavier at 21 mo of age. Due to the low numbers of BW records of mature in-milk cows in the Livestock Improvement Corporation database, this hypothesis was unable to be confirmed. However, considerable variation exists in BW breeding values (which are estimates of mature BW) within Friesian ( -33.3 to $104.7 \mathrm{~kg})$, Jersey (-85.5 to $-6 \mathrm{~kg})$, and Friesian-Jersey crossbred bulls $(-51.3$ to $51.9 \mathrm{~kg}$; DairyNZ, 2018). Future work should be directed at understanding the relationship between heifer BW, BW breeding values, and mature BW in the New Zealand system.

These results show the potential to increase milk production of New Zealand dairy heifers by increasing BW during the rearing phase. Further research on the growth pattern necessary to achieve greater $\mathrm{BW}$ is required.

\section{CONCLUSIONS}

We found a positive curvilinear relationship between BW and milk production in the first-lactation and 3 -parity lactations. Heifers that were heavier produced more milk than heifers that were lighter, regardless of breed group. Consequently, for heifers that had average and below average BW, there would be considerable milk production benefits over the first 3 lactations by improving rearing practices to result in heavier heifers throughout the precalving rearing phase.

\section{ACKNOWLEDGMENTS}

The authors acknowledge Katie Carnie for extracting the data provided by Livestock Improvement Corporation (Hamilton, New Zealand). The first author was funded by Massey University.

\section{REFERENCES}

Archbold, H., L. Shalloo, E. Kennedy, K. M. Pierce, and F. Buckley. 2012. Influence of age, body weight and body condition score before mating start date on the pubertal rate of maiden HolsteinFriesian heifers and implications for subsequent cow performance and profitability. Animal 6:1143-1151. https://doi.org/10.1017/ S1751731111002692.

Archer, S. C., F. Mc Coy, W. Wapenaar, and M. J. Green. 2013. Association between somatic cell count early in the first lactation and the lifetime milk yield of cows in Irish dairy herds. J. Dairy Sci. 96:2951-2959. https://doi.org/10.3168/jds.2012-6294.

Beever, D. E., and P. T. Doyle. 2007. Feed conversion efficiency as a key determinant of dairy herd performance: A review. Aust. J. Exp. Agric. 47:645-657. https://doi.org/10.1071/EA06048.

Bettenay, R. A. 1985. Effect of growth rate and mating age of dairy heifers on subsequent production over four years. Aust. J. Exp. Agric. 25:263-269. https://doi.org/10.1071/EA9850263.

Byerley, D. J., R. B. Staigmiller, J. G. Berardinelli, and R. E. Short. 1987. Pregnancy rates of beef heifers bred either on puberal or third estrus. J. Anim. Sci. 65:645-650. https://doi.org/10.2527/ jas1987.653645x.

DairyNZ. 2018. Ranking of Active Sires. Accessed May 6, 2018. https: //www.dairynz.co.nz/animal/animal-evaluation/ranking-of-active -sires-ras/.

Dobos, R. C., K. S. Nandra, K. Riley, W. J. Fulkerson, I. J. Lean, and R. C. Kellaway. 2001. Effects of age and liveweight at first calving on first lactation milk, protein and fat yield of Friesian heifers. Aust. J. Exp. Agric. 41:13-19. https://doi.org/10.1071/EA00090.

Ettema, J. F., and J. E. P. Santos. 2004. Impact of age at calving on lactation, reproduction, health, and income in first-parity Holsteins on commercial farms. J. Dairy Sci. 87:2730-2742. https:// doi.org/10.3168/jds.S0022-0302(04)73400-1.

Freetly, H. C., L. A. Kuehn, and L. V. Cundiff. 2011. Growth curves of crossbred cows sired by Hereford, Angus, Belgian Blue, Brahman, Boran, and Tuli bulls, and the fraction of mature body weight and height at puberty. J. Anim. Sci. 89:2373-2379. https://doi.org/10 $.2527 /$ jas.2011-3847.

Gilmour, A. R., B. J. Gogel, B. R. Cullis, S. J. Welham, and R. Thompson. 2015. ASReml User Guide Release 4.1 Structural Specification. VSN International Ltd., Hemel Hempstead, UK.

Handcock, R. C., T. Lopdell, and L. R. McNaughton. 2016. More dairy heifers are achieving liveweight targets. Pages 3-7 in Proc. N.Z. Soc. Ani. Prod. Vol. 76, Adelaide, Australia. New Zealand Society of Animal Production, Palmerston North.

Handcock, R. C., N. Lopez-Villalobos, L. R. McNaughton, P. J. Back, G. R. Edwards, and R. E. Hickson. 2018. Live weight and growth of Holstein-Friesian, Jersey and crossbred dairy heifers in New Zealand. N. Z. J. Agric. Res. https://doi.org/10.1080/00288233 .2018.1465984.

Heinrichs, A. J., and B. S. Heinrichs. 2011. A prospective study of calf factors affecting first-lactation and lifetime milk production and age of cows when removed from the herd. J. Dairy Sci. 94:336-341. https://doi.org/10.3168/jds.2010-3170.

Hutchison, J. L., P. M. VanRaden, D. J. Null, J. B. Cole, and D. M. Bickhart. 2017. Genomic evaluation of age at first calving. J. Dairy Sci. 100:6853-6861. https://doi.org/10.3168/jds.2016-12060.

Lembeye, F., N. López-Villalobos, J. L. Burke, and S. R. Davis. 2016. Breed and heterosis effects for milk yield traits at different production levels, lactation number and milking frequencies. N. Z. J. Agric. Res. 59:156-164. https://doi.org/10.1080/00288233.2016 .1156551 . 
Lin, C. Y., A. J. McAllister, T. R. Batra, A. J. Lee, G. L. Roy, J. A. Vesely, J. M. Wauthy, and K. A. Winter. 1988. Effects of early and late breeding of heifers on multiple lactation performance of dairy cows. J. Dairy Sci. 71:2735-2743. https://doi.org/10.3168/ jds.S0022-0302(88)79867-7.

Livestock Improvement Corporation and DairyNZ. 2017. New Zealand Dairy Statistics 2016-17. Livestock Improvement Corporation, DairyNZ, Hamilton, New Zealand. Accessed Dec. 7, 2017. https: //www.dairynz.co.nz/publications/dairy-industry/new-zealand -dairy-statistics-2016-17/.

Macdonald, K. A., J. W. Penno, A. M. Bryant, and J. R. Roche. 2005. Effect of feeding level pre- and post-puberty and body weight at first calving on growth, milk production, and fertility in grazing dairy cows. J. Dairy Sci. 88:3363-3375. https://doi.org/10.3168/ jds.S0022-0302(05)73020-4.

Macdonald, K. A., J. W. Penno, J. A. Lancaster, and J. R. Roche. 2008. Effect of stocking rate on pasture production, milk production, and reproduction of dairy cows in pasture-based systems. J. Dairy Sci. 91:2151-2163. https://doi.org/10.3168/jds.2007-0630.

McNaughton, L. R., and T. Lopdell. 2013. Effect of heifer live weight on calving pattern and milk production. Pages 103-107 in Proc. N.Z. Soc. Ani. Prod. Vol. 73, Hamilton, New Zealand. New Zealand Society of Animal Production, Palmerston North.

McNaughton, L. R., and T. J. Lopdell. 2012. Brief Communication: Are dairy heifers achieving liveweight targets. Pages 120-122 in Proc. N.Z. Soc. Ani. Prod. Vol. 72, Christchurch, New Zealand. New Zealand Society of Animal Production, Palmerston North.

McNaughton, L. R., S. R. Morgan, P. Gore, G. A. Verkerk, C. W. Holmes, and T. J. Parkinson. 2002. Monitoring onset of puberty in three genetic strains of Holstein-Friesian dairy cattle. Pages 30-33 in Proc. N.Z. Soc. Ani. Prod. Vol. 62, Palmerston North, New Zealand. New Zealand Society of Animal Production, Palmerston North.

NRC. 2001. Growth. Pages 238-243 in Nutrient Requirements of Dairy Cattle. 7th rev. ed. Natl. Acad. Press, Washington, DC.

Pryce, J. E., B. L. Harris, and L. R. McNaughton. 2007. The genetic relationship between heifer and cow fertility. Pages 388-391 in
Proc. N.Z. Soc. Ani. Prod. Vol. 67, Wanaka, New Zealand. New Zealand Society of Animal Production, Palmerston North.

Sneddon, N. W., N. Lopez-Villalobos, S. R. Davis, R. E. Hickson, L. Shalloo, and D. J. Garrick. 2016. Estimates of genetic and crossbreeding parameters for milk components and potential yield of dairy products from New Zealand dairy cattle. N. Z. J. Agric. Res. 59:79-89. https://doi.org/10.1080/00288233.2015.1131723.

Soberon, F., E. Raffrenato, R. W. Everett, and M. E. Van Amburgh. 2012. Preweaning milk replacer intake and effects on long-term productivity of dairy calves. J. Dairy Sci. 95:783-793. https://doi .org/10.3168/jds.2011-4391.

Troccon, J. L. 1993. Effects of winter feeding during the rearing period on performance and longevity in dairy cattle. Livest. Prod. Sci. 36:157-176. https://doi.org/10.1016/0301-6226(93)90149-C.

Tyrrell, H. F., and J. T. Reid. 1965. Prediction of the energy value of cow's milk. J. Dairy Sci. 48:1215-1223. https://doi.org/10.3168/ jds.S0022-0302(65)88430-2.

Van Amburgh, M. E., D. M. Galton, D. E. Bauman, R. W. Everett, D. G. Fox, L. E. Chase, and H. N. Erb. 1998. Effects of three prepubertal body growth rates on performance of Holstein heifers during first lactation. J. Dairy Sci. 81:527-538. https://doi.org/10.3168/ jds.S0022-0302(98)75604-8.

van der Waaij, E. H., P. J. B. Galesloot, and D. J. Garrick. 1997. Some relationships between weights of growing heifers and their subsequent lactation performances. N. Z. J. Agric. Res. 40:87-92. https: //doi.org/10.1080/00288233.1997.9513235.

Van Eetvelde, M., M. M. Kamal, L. Vandaele, and G. Opsomer. 2017. Season of birth is associated with first-lactation milk yield in Holstein Friesian cattle. Animal 11:2252-2259. https://doi.org/10 .1017/S1751731117001021.

Wathes, D. C., G. E. Pollot, K. F. Johnson, H. Richardson, and J. S. Cooke. 2014. Heifer fertility and carry over consequences for life time production in dairy and beef cattle. Animal 8:91-104. https: //doi.org/10.1017/S1751731114000755. 